\title{
Tüketicilerin çiğ süt satın alma eğilimlerinin saptanması: İzmir ili Örneği
}

\section{Determination of consumers' purchasing intentions of raw milk: The case of Izmir}

\author{
Ahmet SEVIM@, Özlem ARSLAN@, Duran GÜLER $₫$, Gamze SANER \\ Ege Üniversitesi, Ziraat Fakültesi, Tarım Ekonomisi Bölümü, 35100, İzmir \\ Sorumlu yazar (Corresponding author): D. Güler, e-posta (e-mail): duran.guler@ege.edu.tr \\ Yazar(lar) e-posta (Authore-mail): ahmet.svm17@gmail.com,ozars@hotmail.com,gamze.saner@edu.tr
}

\section{MAKALE BİLGİSİ}

Alınış tarihi 05 Aralık 2019

Düzeltilme tarihi 29 Ocak 2021

Kabul tarihi 29 Ocak 2021

\section{Anahtar Kelimeler:}

Tüketici tercihleri

Çiğ süt tüketimi

Satın alma eğilimi

İzmir

\begin{abstract}
ÖZ
$\mathrm{Bu}$ araştırmanın temel amacı İzmir ilinde tüketicilerin çiğ süt satın alma eğilimlerinin saptanmasıdır. $\mathrm{Bu}$ amaç doğrultusunda öncelikle tüketicilerin sosyo-ekonomik özellikleri verilmiş, çiğ süt ile ilgili bilgi düzeyleri belirlenmiş ve çiğ süt satın alma eğilimlerini etkileyebilecek faktörler ortaya konulmuştur. Çalışmanın verileri İzmir ilinin en fazla nüfusa sahip olan ilk 10 ilçesinde tüketicilerle yüz yüze yapılan anket çalıșmasından elde edilmiștir. Araştırma sonuçları çiğ süt tüketim miktarında tüketici gelirinin etkili olmadığını, ancak tüketici geliri arttıkça satın alınan çiğ süte ödenen fiyatın arttığını göstermiştir. Ayrıca eğitim düzeyi ve geliri yüksek olan tüketicilerin çiğ sütü genellikle mandıralardan satın almayı tercih ettikleri belirlenmiştir. Tüketiciler çiğ süt satın alırken fiyattan çok damak tadına ve hijyen koşullarına önem vermektedirler. Bu nedenle çiğ süt tüketimini teşvik etmeye yönelik tanıtımların tedarik zincirindeki hijyen koşulları ön plana çıkarılarak yapılması çiğ süt tüketimini arttırabilecektir. Ayrıca, çiğ sütün soğuk zincirde pazarlanmasının gelecekte kayıt dışı pazarlanan süt oranını azaltabileceği tahmin edilmektedir.
\end{abstract}

\section{ARTICLE INFO}

Received 05 December 2019

Received in revised form 29 January 202

Accepted 29 January 2021

Keywords:

Consumer preferences

Raw milk consumption

Purchase intention

Izmir

\begin{abstract}
The main aim of this study is to determine the intentions of consumers to buy raw milk in Izmir province. Within the scope of this aim, the socio-economic characteristics of consumers were given firstly, the level of information about raw milk was determined, and the factors that may affect the intentions of purchasing raw milk were determined. The data of the study was obtained from the face-to-face surveys conducted with consumers in the top 10 districts of the province with the highest population. Research results show that the consumers' income is not effective in raw milk consumption, but that the purchasing price for raw milk increases as consumers' income increases. In addition, it was determined that consumers with high educational level and income preferred to purchase raw milk from dairies. When buying raw milk, consumers give more importance to taste and hygiene than price. Therefore, promotion of raw milk consumption by highlighting hygiene conditions in the supply chain can increase raw milk consumption. It is also estimated that the marketing of raw milk in the cold chain will reduce the rate of informal milk marketed in the future.
\end{abstract}

\section{Giriş}

Süt, canlının büyümesi ve gelişmesi için başta gelen besinlerden biri olup, yeterli ve dengeli beslenme için gerekli olan hayvansal kaynaklı protein, yağ, laktoz, vitamin ve mineral maddeleri tam ve yeterli oranda içermektedir. Süt, sağlıklı süt hayvanlarının sağılması ile elde edilen kolostrum dışında en az $\% 8.25$ yağsız süt kuru maddesi ve $\% 3.25$ süt yağı içeren taze meme salgısı olarak tanımlanmaktadır (Tekinşen ve Tekinşen 2005; Günlü 2011). Besin değeri yüksekliğinin yanı sıra vücut fonksiyonlarını düzenleyen ve gelişmesini sağlayan süt; kemik ve diş oluşumunda önemli rolü olan temel bir gida maddesidir (Şimşek ve ark. 2005).
İnsanların günlük tüketmesi gereken süt miktarı kişinin durumuna göre değişmektedir. Günlük olarak tüketilmesi önerilen süt miktarı bebekler için $700 \mathrm{gr}$, çocuklar için $400 \mathrm{gr}$, gençler için 350 gr, yetişkinler için 250 gr, hamile ve bebek emziren kadınlar için 500 gr ve yaşlılar için 350 gr'dır (Ayar ve Demirulus 2000; Çelik ve ark. 2005).

Gıda Tarım ve Hayvancılık Bakanlığı (GTHB) tarafindan hazırlanan 30050 sayılı "Çĭ̆ Sütün Arzına Dair Tebliğ" 27 Nisan 2017 tarihinde Resmî Gazetede yayınlanarak yürürlüğe girmiştir. Çiğ süt satış kriterlerinin belirlendiği bu tebliğde çiğ 
süt arzının sadece hastalıktan ari işletmeler tarafından gerçekleştirilmesinin zorunlu olduğu belirtilmiştir (Resmî Gazete 2017). Böylece yasal olarak soğuk zincirde çiğ süt satışının önü açılmış ve çiğ süt market raflarında yerini bulmuştur. $\mathrm{Bu}$ durum açık süt tüketiminin, dolayısıyla çiğ süt satın alma eğiliminin araştırılmasını daha fazla önemli duruma getirmektedir. Türkiye'de 2018 y1lında üretilen 20.04 milyon ton sütün \%8.29'u (1.66 milyon ton) ambalajlı içme sütü olarak tüketime arz edilmiştir (USK 2019). Sokak satıcıları tarafından satışı yapılan çiğ süt miktarına ilişkin veriler mevcut olmadığ 1 için çiğ süt olarak pazarlanan süt miktarı ile ilgili net veriler elde edilememiştir. Çiğ süt, bazı çalışmalarda 'açık süt' olarak da adlandırılmaktadır. Bu çalışmada her iki adlandırmayı aynı anda kullanmaktan kaçınılmış ve sadece çiğ süt olarak belirtilmiştir

Türkiye'de çiğ süt tüketimine yönelik bazı çalışmaların yapıldığı görülmektedir (Andiç ve ark. 2002; Çelik ve ark. 2005; Akbay ve Yıldız Tiryaki 2007; Çetinkaya 2010; Demircan ve ark. 2011; Erdal ve Tokgöz 2011; Karakaya ve Akbay 2014; Gözener ve Sayılı 2013; Uzundumlu ve Birinci 2013; Kahraman 2016; Çebi ve ark. 2018).

Çalışmanın temel amacı; İzmir ilinde tüketicilerin çiğ süt satın alma eğilimlerinin saptanmasıdır. Çalışmanın diğer amaçları İzmir ilinde çiğ süt tüketicilerinin çiğ süt satın alma eğilimlerini etkileyen demografik yapıların, çiğ sütü değerlendirme şekillerinin, satın alınan çiğ süt fiyatının ve çiğ sütten bulaşabilecek hastalıklar hakkındaki bilgi düzeylerinin belirlenmesidir. $\mathrm{Bu}$ çalışma, çiğ süt satış kriterlerindeki güncel gelişmelerden sonra, İzmir ilindeki tüketicilerin çiğ süt satın alımına yönelik eğilimlerinin belirlenmesine katkı sağlanması açısından önemlidir.

Ayrıca, bu çalışmanın tüketicilerin çiğ süt satın alma eğilimlerinin anlaşılabilir olmasına katkı sağlamasının yanı sıra ilgili kurum ve kuruluşlara ve süt üreten işletmelere tüketicilerin beklentilerini karşılayabilmeleri konusunda yol gösterici olması beklenmektedir.

\section{Materyal ve Yöntem}

Çalışmanın verileri İzmir ilinin en fazla nüfusa sahip olan ilk 10 ilçesinde tüketicilerle yüz yüze yapılan anket çalışmasından elde edilen birincil verilerden oluşmaktadır. Ayrıca, ilgili kurumların yayınladığı istatistiklerden ve bu konuda yapılan araştırma sonuçlarından da yararlanılmıştır.

Anket çalışmasında görüşülecek tüketici sayısı belirlenirken bu ilçelerde yaşayan hane halkı sayısı dikkate alınmıştır. İzmir ilinde Adrese Dayalı Nüfus Kayıt Sistemi verilerine göre 2016 y1lı itibariyle 4223545 kişi bulunmaktadır (TÜİK 2016). Araştırmada örnek hacminin belirlenmesinde, İzmir ilinde bulunan en fazla nüfusa sahip ilk 10 ilçesinde çiğ süt tüketen tüketici sayısı dikkate alınmıştır. Örnek hacmi; \%99 güven aralığı ve \%10 hata payı esas alınarak 166 kişi olarak hesaplanmıştır. Anket yapılacak tüketicilerin ilçelere göre dağılımında toplam hane sayısı içinde ilçelerin aldığı oran esas alınmıştır (Çizelge 1). Anket çalışmaları hane halkı ile 2017 yılı Kasım ve 2018 yılı Şubat ayları arasında gerçekleştirilmiştir.

Örnek hacminin belirlenmesinde oransal örnek hacmi formülü kullanılmıştır (Newbold 1995):

$$
n=\frac{N p(1-p)}{(N-1) \sigma_{p_{x}}^{2}+p(1-p)}
$$

Formülde;

$n=$ Örnek hacmi,

$p=$ Oran (maksimum örnek hacmine ulaşmak amacıyla $p=0.5$ alınmıştır.),

$N=$ Anakitle,

$\sigma_{p_{x}}^{2}=$ Oranın varyansıdır.

Verileri toplamak amacıyla hazırlanan anket formlarında, tüketicilerin demografik ve sosyo-ekonomik özellikleri ile çĭ̆ süt satın alma eğilimlerini saptamaya yönelik sorulara yer verilmiştir.

Çalışmada üreticilerden elde edilen verilerin değerlendirilmesinde öncelikle yüzde ve ortalamalar gibi temel istatistiksel yöntemlere yer verilmiş, elde edilen sonuçlar çizelgelerde gösterilmiştir. Araştırmada temel düzeyde basit tanımlayıcı istatistiklerden, parametrik ve parametrik olmayan testlerden yararlanılmıştır.

Mevcut anket verilerinin analiz edilmesinde SPSS ve Excel paket programları kullanılmıştır.

Araştırma kapsamında elde edilen verilerle çiğ süt tüketicilerinin tüketim tercihleri istatistiksel olarak test edilmiştir. Normal dağılış göstermeyen ve varyansı homojen olmayan sürekli değişkenler için iki grubu karşılaştırmak amaciyla Mann-Whitney $U$ testi, ikiden daha fazla grubu karşılaştırmak amacıyla ise Kruskall-Wallis testi uygulanmıştır. Ayrıca grupları karşılaştırmak amacıyla kesikli değişkenlerin analizinde Ki-kare testi yapılmıştır.

Verilerin analizinde; öncelikle tüketicilerin demografik ve sosyo-ekonomik özellikleri ortaya konulmuştur. Bu aşamada; tüketicilerin yaşı, eğitim durumu, medeni durumu, çalışma durumu, aile nüfusu, aylık gelir düzeyi vb. özellikleri incelenmiştir.

Ankete katılan tüketicilerin çiğ sütle ilgili bilgi düzeylerinin ve çiğ süt satın almada önem verdikleri faktörlerin değerlendirilmesinde likert ölçeği kullanılmıştır. Likert ölçeğine göre, tutum ölçeğinde yer alan ifadeler 5'li ölçeğe göre (1. Kesinlikle katılmıyorum - 5. Kesinlikle katılıyorum) değerlendirilmiştir.

\section{Bulgular ve Tartışma}

Ankete katılan tüketicilere ilişkin demografik ve sosyoekonomik özellikler Çizelge 2'de sunulmuştur. Buna göre görüşülen tüketicilerin \%71.69'unu kadınlar, \%28.31'ini erkekler oluşturmaktadır. Tüketicilerin yaş ortalaması 45.50 olup, \%54.22'si 31-50 yaş grubunda yer almaktadır. Tüketicilerin \%31.93'ü ilköğretim, \%24.10'u lise ve \%43.98'i lisans mezunudur. Medeni durumları bakımından yüksek oranda (\%74.10) evli oldukları belirlenen tüketicilerin \%23.49'u ev hanımı ve yine \%23.49'u özel sektör çalışanıdır. Hanehalk1 geliri bakımından değerlendirilen tüketicilerin \%39.76'sının 3000 TL altında, \%34.94'ünün ise 3001-5000 TL aralığında aylık gelire sahip oldukları belirlenmiştir.

Tüketicilerin \%98.80'i çĭg sütü yoğurt-tatlı yapımında, $\% 60.24$ 'ü ise içme sütü olarak değerlendirdiklerini belirtmişlerdir. Tüketicilerin \%82.53'ünün satın aldıkları çiğ süte 2.10-4.00 TL aralığında ücret ödedikleri saptanmıştır (Çizelge 3).

Görüşülen tüketicilerin \%38.55'i (64 kişi) çiğ sütü mandıradan, \%36.14'ü (60 kişi) sokak satıcısından, \%14.46'i 
Çizelge 1. Nüfusun ilçelere göre dağılımı (2016).

Table 1. Population distribution by districts (2016).

\begin{tabular}{|c|c|c|c|c|}
\hline İlçeler & Nüfus & Hane Sayısı & $\begin{array}{c}\text { Hane Sayısının Ana Kitleye } \\
\text { Oranı }(\%)\end{array}$ & $\begin{array}{c}\text { Anket Yapılacak Tüketici } \\
\text { Sayısı }\end{array}$ \\
\hline Buca & 482337 & 158663 & 15.70 & 26 \\
\hline Karabağlar & 480253 & 157978 & 15.63 & 26 \\
\hline Bornova & 438549 & 144260 & 14.28 & 24 \\
\hline Konak & 370662 & 121928 & 12.07 & 20 \\
\hline Karşıyaka & 338485 & 111344 & 11.02 & 18 \\
\hline Bayraklı & 314008 & 103292 & 10.22 & 17 \\
\hline Çiğli & 186717 & 61420 & 6.08 & 10 \\
\hline Torbalı & 164981 & 54270 & 5.37 & 9 \\
\hline Menemen & 163565 & 53804 & 5.32 & 9 \\
\hline Gaziemir & 132566 & 43607 & 4.32 & 7 \\
\hline TOPLAM & 3072123 & 1010566 & 100 & 166 \\
\hline
\end{tabular}

Çizelge 2. Tüketicilerin demografik ve sosyo-ekonomik özellikleri.

Table 2. Consumers' demographic and socio-economic characteristics.

\begin{tabular}{|c|c|c|}
\hline Özellikler & Sayı & Oran $(\%)$ \\
\hline Toplam Tüketici & 166 & 100.00 \\
\hline \multicolumn{3}{|l|}{ Cinsiyet } \\
\hline Kadın & 119 & 71.69 \\
\hline Erkek & 47 & 28.31 \\
\hline \multicolumn{3}{|l|}{ Yaş } \\
\hline $18-30$ & 20 & 12.05 \\
\hline $31-50$ & 90 & 54.22 \\
\hline$>50$ & 56 & 33.73 \\
\hline \multicolumn{3}{|l|}{ Eğitim Durumu } \\
\hline İlköğretim & 53 & 31.93 \\
\hline Lise & 40 & 24.10 \\
\hline Yükseköğretim & 73 & 43.98 \\
\hline \multicolumn{3}{|l|}{ Medeni Durum } \\
\hline Bekar & 25 & 15.06 \\
\hline Evli & 123 & 74.10 \\
\hline Ayrılmış / Eşi Vefat Etmiş & 18 & 10.84 \\
\hline \multicolumn{3}{|l|}{ Meslek } \\
\hline Ev Hanımı & 39 & 23.49 \\
\hline Öğrenci & 13 & 7.83 \\
\hline Kamu Çalışanı & 24 & 14.46 \\
\hline Özel Sektör Çalışanı & 39 & 23.49 \\
\hline Emekli & 33 & 19.88 \\
\hline Diğer & 18 & 10.84 \\
\hline \multicolumn{3}{|l|}{ Hanehalkı Geliri (Aylık) } \\
\hline$<3000 \mathrm{TL}$ & 66 & 39.76 \\
\hline $3001-5000 \mathrm{TL}$ & 58 & 34.94 \\
\hline$>5000 \mathrm{TL}$ & 42 & 25.30 \\
\hline
\end{tabular}

Çizelge 3. Tüketicilerin çiğ sütü değerlendirme şekli ve çiğ süt satın alma fiyatları.

Table 3. Evaluation of raw milk by consumers and raw milk purchasing prices.

\begin{tabular}{lrr}
\hline Çiğ Sütün Değerlendirilme Şekli & Sayı & Oran(\%) \\
\hline Yoğurt-Tatlı Yapımı & 164 & 98.80 \\
İçme Sütü & 100 & 60.24 \\
\hline Çiğ Süt Fiyatı (TL L L $\left.{ }^{-1}\right)$ & & \\
\hline$<2.00$ & 137 & 15.06 \\
$2.10-4.00$ & 1 & 82.53 \\
$4.10-6.00$ & 3 & 0.60 \\
$>6.00$ & $\mathbf{1 6 6}$ & 1.81 \\
\hline Toplam & $\mathbf{1 0 0 . 0}$ \\
\hline
\end{tabular}


(24 kişi) üreticinin evinden ve \%10.84'ü (18 kişi) marketten satın aldığını belirtmişlerdir.

Tüketicilerin çiğ süt ile bilgi edinme kaynakları incelendiğinde büyük oranda (\%96.39) sosyal çevrelerinden bilgi edindikleri saptanmıştır. Tire Süt Kooperatifi tarafından sunulan Alo Süt Hattı hizmetinden bilgi edinenlerin oranı ise \%3.01'dir (Çizelge 4).

Tüketicilere çiğ sütten bulaşabilecek hastalıklarla ilgili bilgi düzeyleri sorulduğunda 78 kişi Brucella, 15 kişi Tüberküloz, 13 kişi Salmonella, 8 kişi Kolera, 8 kişi enfeksiyon ve 7 kişi şap hastalığını bildiğini belirtmiştir. Septisemi, Şakağı, Şarbon, Gut, Stophylococus, Sarılık, Mastitis, Solos, Toksoplazma hastalıklarının bilinirliğinin ise oldukça az olduğu belirlenmiştir.

Tüketicilerin çiğ süt satın almalarına yönelik tutumları değerlendirildiğinde; tüketicilerin "UHT ve pastörize sütle fiyatı ayn olsa da çiğ süt almaya devam ederim”, "markette satılan çiğ süt damak tadıma uymazsa sokak sütçüsünden satın almaya devam ederim”, "çiğ süt üreticisi ve taşıma kapları hijyenik değilse çiğ süt satın almaktan vazgeçerim” ifadelerine katılım oranları yüksek olarak saptanmıştır. "Fiyat yükselirse çiğ süt satın almam" ve "kapıya kadar getirilmezse çiğ süt satın almam" ifadelerine katılım oranları ise düşük olarak saptanmıştır (Çizelge 5).

Satın alınan çiğ süt fiyatı bakımından tüketicilerin cinsiyet, yaş ve eğitim düzeyi gruplarına göre istatistiksel olarak farklılık olmadığı; ancak gelir durumlarına göre farklılık olduğu $\left(\chi^{2}=\right.$ $11.704, p=0.003)$ belirlenmiştir. Buna göre gelir düzeyi yüksek olan tüketiciler çiğ süte daha fazla fiyat ödemektedirler (Çizelge 6). Karakaya ve Akbay (2014) tarafindan İstanbul ilinde yapılan çalışmada çiğ süt tüketiminde fiyatın ucuz olmasının tüketiciler tarafından çok önemli bulunmadığı, Uzundumlu ve Birinci
(2013) tarafindan Erzurum ilinde yapılan çalışmada ise tüketicilerin sadece \%9'unun fiyata öncelik verdikleri saptanmıştır.

Hane halkı tarafından satın alınan ortalama çiğ süt miktarı haftalık 4.30 L'dir. Haftalık satın alınan çiğ süt miktarı değerlendirildiğinde ise tüketicilerin cinsiyet, yaş, eğitim düzeyi ve gelir gruplarına göre istatistiksel olarak farklılık olmadığ belirlenmiştir (Çizelge 7). Karakaya ve Akbay (2014) tarafından yapılan çalışmada da çiğ süt tüketim miktarının cinsiyet, eğitim ve gelir düzeyine göre farklılık göstermediği saptanmıştır.

Tüketicilerin demografik özellikleri ile çiğ süt satın alınan yer arasındaki ilişki incelendiğinde eğitim düzeyi yüksek, geliri fazla, 40 yaşında ve bu yaşın altında olan tüketicilerin çiğ sütü genellikle mandıralardan satın aldıkları ve bu bakımdan gruplar arasında istatistiksel açıdan farklılık bulunduğu saptanmıştır. Tüketicilerin cinsiyeti ile çiğ süt alınan yer arasında bir ilişki bulunmamaktadır (Çizelge 8). Literatürdeki çalışmalar çiğ süt satın alınan yerler açısından değerlendirildiğinde; Demircan ve ark. (2011) tarafindan Isparta ilinde yapılan çalışmada tüketicilerin \%60'ının çiğ sütü haftanın belirli günlerinde köyden süt getiren üreticilerden, Erdal ve Tokgöz (2011) tarafından Erzincan ilinde yapılan çalışmada tüketicilerin \%61'inin kapılarına sütü getiren kişilerden, Gözener ve Sayılı (2013) tarafından Tokat ilinde yapılan çalışmada tüketicilerin \%92'sinin tanıdıklarından, Çebi ve ark. (2018) tarafından Erzincan ilinde yapılan çalışmada tüketicilerin \%70'inin sokak satıcılarından ve doğrudan üreticilerden satın aldıkları saptanmıştır. Bu çalışmada ise tüketicilerin \%39'unun çiğ sütü mandıralardan, \%36'sının ise sokak satıcılarından satın aldıkları ve bu bakımdan İzmir ilinin önceki çalışmalarda yer alan illerden farklılık gösterdiği belirlenmiştir.

Çizelge 4. Tüketicilerin çiğ süt ile ilgili bilgi kaynakları.

Table 4. Consumers' information sources related to raw milk.

\begin{tabular}{lrr}
\hline Kaynaklar & Kişi Sayısı* & (\%) \\
\hline Sosyal Çevre (Aile, Arkadaşlar, Satıcı vb.) & 160 & 96.39 \\
Yayın Organları (Televizyon, Radyo) & 56 & 33.73 \\
Sosyal Medya (İnternet, Facebook, Twitter, Instagram vb.) & 30 & 18.07 \\
Yazılı Medya (Gazete, Dergi) & 24 & 5.46 \\
Alo Süt Hattı (Tire Süt) & 5 & 3.01 \\
\hline
\end{tabular}

Alo Süt Hattı (Tire Süt)

Çizelge 5. Tüketicilerin çiğ süt satın almalarına yönelik tutumları.

Table 5. Consumers' attitudes towards raw milk purchase.

\begin{tabular}{|c|c|c|}
\hline Faktörler & Ortalama & Standart Sapma \\
\hline UHT ve pastörize sütle fiyatı aynı olsa da çiğ süt almaya devam ederim & 4.45 & 0.975 \\
\hline Markette satılan çiğ süt damak tadıma uymazsa sokak sütçüsünden satın almaya devam ederim & 4.03 & 1.262 \\
\hline Çiğ süt taşıma kapları hijyenik değilse çiğ süt satın almaktan vazgeçerim & 4.00 & 1.393 \\
\hline Denetlenmemiş işletme ve/veya üreticilerden çiğ süt almam & 3.79 & 1.443 \\
\hline Çiğ sütün kokusunu/rengini beğenmezsem bir daha satın almam & 3.77 & 1.467 \\
\hline Sokakta süt satışı yasaklanırsa sütü işletmeden almaya giderim & 3.69 & 1.320 \\
\hline Çiğ süt nedeniyle rahatsızlanırsam tekrar çiğ süt satın almam & 3.48 & 1.447 \\
\hline Çiğ sütün yağ oranı düşük olursa / kaymağı az olursa almam & 3.18 & 1.466 \\
\hline Sütün içinden yabancı maddeler çıkarsa çiğ süt almaktan vazgeçerim (çöp, saman, sinek vs.) & 3.10 & 1.559 \\
\hline Markette satılan paketlenmiş çiğ sütü sokakta satılan paketli olmayan çiğ süte tercih ederim & 2.92 & 1.523 \\
\hline Yoğurt veya tatlı yapmasaydım çiğ süt satın almazdım & 2.87 & 1.571 \\
\hline Marketlerde bulabilirsem çiğ sütü sadece marketten alırım & 2.80 & 1.386 \\
\hline Sokakta satılan çiğ sütün fiyatı markette satılandan yüksek olursa sokak sütçüsünden almaktan vazgeçerim & 2.67 & 1.441 \\
\hline Markette satılan çiğ sütün fiyatı UHT ve pastörize sütten pahalı olursa çiğ süt almaktan vazgeçerim & 2.46 & 1.425 \\
\hline Medyada olumsuz haberler çıkarsa çiğ süt satın almam & 2.27 & 1.295 \\
\hline Fiyat yükselirse çiğ süt satın almam & 1.93 & 1.163 \\
\hline Kapıya kadar getirilmezse çiğ süt satın almam & 1.93 & 1.268 \\
\hline
\end{tabular}

1.Kesinlikle katılmıyorum, 2. Katılmıyorum, 3. Orta derecede katılıyorum, 4. Kat1lıyorum, 5. Kesinlikle katılıyorum. 
Çizelge 6. Tüketicilerin demografik özelliklerine göre satın alınan çiğ süt fiyatı.

Table 6. The purchasing price of raw milk by consumers' demographic characteristics.

\begin{tabular}{|c|c|c|c|c|c|c|c|}
\hline Değişkenler & Tüketici Grupları & $\begin{array}{c}\text { Kişi } \\
\text { Sayısı }\end{array}$ & $\begin{array}{c}\text { Ort. Çiğ Süt } \\
\text { Fiyatı ( TL/L) }\end{array}$ & Std. Sapma & $\chi^{2}$ & $\begin{array}{c}\text { Mann- } \\
\text { Whitney U }\end{array}$ & $\mathbf{p}$ \\
\hline \multirow[t]{2}{*}{ Cinsiyet } & Kadın & 119 & 2.75 & 0.99 & \multirow[b]{2}{*}{-} & \multirow{2}{*}{2582.50} & \multirow{2}{*}{0.424} \\
\hline & Erkek & 47 & 2.54 & 0.55 & & & \\
\hline \multirow{3}{*}{ Yaş } & $18-30$ & 20 & 2.47 & 0.61 & \multirow{3}{*}{3.013} & \multirow{3}{*}{-} & \multirow{3}{*}{0.222} \\
\hline & $31-50$ & 90 & 2.58 & 0.58 & & & \\
\hline & $>50$ & 56 & 2.68 & 0.90 & & & \\
\hline \multirow{3}{*}{ Eğitim } & İlköğretim & 53 & 2.45 & 0.29 & \multirow{3}{*}{3.408} & \multirow{3}{*}{ - } & \multirow{3}{*}{0.182} \\
\hline & Lise & 40 & 2.60 & 0.84 & & & \\
\hline & Yükseköğretim & 73 & 2.71 & 0.82 & & & \\
\hline \multirow{3}{*}{ Gelir*** } & $<3000 \mathrm{TL}$ & 66 & 2.52 & 0.65 & \multirow{3}{*}{11.704} & \multirow{3}{*}{-} & \multirow{3}{*}{0.003} \\
\hline & $3001-5000 \mathrm{TL}$ & 58 & 2.49 & 0.45 & & & \\
\hline & $>5000 \mathrm{TL}$ & 42 & 2.89 & 0.97 & & & \\
\hline
\end{tabular}

Kruskal Wallis testine göre gruplar arasındaki fark $* * * \mathrm{p}<0.01$ düzeyinde anlamlıdır.

Çizelge 7. Tüketicilerin demografik özelliklerine göre satın alınan çiğ süt miktarı.

Table 7. The quantity of raw milk purchased according to consumers' demographic characteristics.

\begin{tabular}{|c|c|c|c|c|c|c|c|}
\hline Değiş̧kenler & Tüketici Grupları & $\begin{array}{c}\text { Kişi } \\
\text { Sayısı }\end{array}$ & $\begin{array}{c}\text { Satın Alınan Çiğ } \\
\text { Süit Miktarı } \\
\text { (L/Hafta) }\end{array}$ & $\begin{array}{c}\text { Std. } \\
\text { Sapma }\end{array}$ & $\chi^{2}$ & $\begin{array}{c}\text { Mann- } \\
\text { Whitney U }\end{array}$ & $\mathbf{p}$ \\
\hline Cinsiyet & $\begin{array}{l}\text { Kadın } \\
\text { Erkek }\end{array}$ & $\begin{array}{r}119 \\
47\end{array}$ & $\begin{array}{l}4.56 \\
4.14 \\
\end{array}$ & $\begin{array}{l}1.94 \\
1.46\end{array}$ & - & 2454.00 & 0.196 \\
\hline Yaş & $\begin{array}{l}18-30 \\
31-50 \\
>50 \\
\end{array}$ & $\begin{array}{l}20 \\
90 \\
56 \\
\end{array}$ & $\begin{array}{l}4.28 \\
4.37 \\
4.09 \\
\end{array}$ & $\begin{array}{l}1.83 \\
1.62 \\
1.55 \\
\end{array}$ & 0.791 & - & 0.673 \\
\hline Eğitim & $\begin{array}{l}\text { İlköğretim } \\
\text { Lise } \\
\text { Yükseköğretim }\end{array}$ & $\begin{array}{l}53 \\
40 \\
73 \\
\end{array}$ & $\begin{array}{l}4.25 \\
4.68 \\
4.04 \\
\end{array}$ & $\begin{array}{l}1.75 \\
1.67 \\
1.45 \\
\end{array}$ & 2.690 & - & 0.261 \\
\hline Gelir & $\begin{array}{l}<3000 \mathrm{TL} \\
3001-5000 \mathrm{TL} \\
>5000 \mathrm{TL}\end{array}$ & $\begin{array}{l}66 \\
58 \\
42 \\
\end{array}$ & $\begin{array}{l}4.07 \\
4.12 \\
4.76 \\
\end{array}$ & $\begin{array}{l}1.60 \\
1.32 \\
1.92 \\
\end{array}$ & 4.227 & - & 0.121 \\
\hline
\end{tabular}

Çizelge 8. Tüketicilerin demografik özellikleri ile çiğ süt satın alınan yer arasındaki ilişki.

Table 8. The relationship between consumers' demographic characteristics and the place where raw milk is purchased.

\begin{tabular}{|c|c|c|c|c|c|c|c|c|}
\hline $\begin{array}{l}\text { Tüketici } \\
\text { Grupları }\end{array}$ & Değişkenler & $\begin{array}{c}\text { Sayı ve } \\
\%\end{array}$ & $\begin{array}{c}\text { Sokak } \\
\text { Satıcısı }\end{array}$ & Market & $\begin{array}{c}\text { Üretici } \\
\text { Evi }\end{array}$ & Mandıra & $\chi^{2}$ & $\mathbf{p}$ \\
\hline \multirow{4}{*}{ Cinsiyet } & & Sayı & 12 & 4 & 10 & 21 & \multirow{4}{*}{5.119} & \multirow{4}{*}{0.163} \\
\hline & Kadin & $\%$ & 25.53 & 8.51 & 21.28 & 44.68 & & \\
\hline & \multirow[b]{2}{*}{ Erkek } & Sayı & 48 & 14 & 14 & 43 & & \\
\hline & & $\%$ & 40.34 & 11.76 & 11.76 & 36.13 & & \\
\hline \multirow{4}{*}{ Yaş*** } & \multirow{2}{*}{$18-40$} & Sayı & 13 & 3 & 14 & 25 & \multirow{4}{*}{13.659} & \multirow{4}{*}{0.003} \\
\hline & & $\%$ & 23.64 & 5.45 & 25.45 & 45.45 & & \\
\hline & \multirow{2}{*}{$>40$} & Sayı & 47 & 15 & 10 & 39 & & \\
\hline & & $\%$ & 42.34 & 13.51 & 9.01 & 35.14 & & \\
\hline \multirow{6}{*}{ Eğitim* } & \multirow{2}{*}{ İlköğretim } & Sayı & 27 & 5 & 5 & 16 & \multirow{6}{*}{11.321} & \multirow{6}{*}{0.079} \\
\hline & & $\%$ & 50.94 & 9.43 & 9.43 & 30.19 & & \\
\hline & & Sayı & 14 & 4 & 9 & 13 & & \\
\hline & Lise & $\%$ & 35.00 & 10.00 & 22.50 & 32.50 & & \\
\hline & \multirow{2}{*}{ Yükseköğretim } & Sayı & 19 & 9 & 10 & 35 & & \\
\hline & & $\%$ & 26.03 & 12.33 & 13.70 & 47.95 & & \\
\hline \multirow{6}{*}{ Gelir** } & \multirow{2}{*}{$<3000 \mathrm{TL}$} & Say1 & 33 & 6 & 8 & 19 & \multirow{6}{*}{13.339} & \multirow{6}{*}{0.038} \\
\hline & & $\%$ & 50.00 & 9.09 & 12.12 & 28.79 & & \\
\hline & $3001-5000 \mathrm{TL}$ & Sayı & 20 & 5 & 9 & 24 & & \\
\hline & $3001-50001 \mathrm{~L}$ & $\%$ & 34.48 & 8.62 & 15.52 & 41.38 & & \\
\hline & \multirow{2}{*}{$>5000 \mathrm{TL}$} & Sayı & 7 & 7 & 7 & 21 & & \\
\hline & & $\%$ & 16.67 & 16.67 & 16.67 & 50.00 & & \\
\hline
\end{tabular}

Ki-kare testine göre gruplar arasındaki fark $* * * \mathrm{p}<0.01,{ }^{* *} \mathrm{p}<0.05$ ve $* \mathrm{p}<0.1$ düzeyinde anlamlıdır.

\section{Sonuç}

Çalışmada elde edilen sonuçlar tüketicilerin çiğ sütü özellikle yoğurt ve tatlı yapımı için satın aldıklarını göstermektedir. Bununla birlikte içme sütü olarak değerlendirmek üzere satın alanların oranı (\%60.24) da yüksektir. Çiğ süt talebindeki bu belirgin tüketici tercihi, çiğ süt tüketimine yönelik yapılacak tanıtımlarda ön plana çıkarılabilir.
Bununla birlikte çiğ süt fiyatının UHT ve pastörize süt fiyatıyla aynı olsa da tüketicilerin çiğ süt almaya devam edeceklerini belirtmeleri çiğ süt tercihinde temel kriterin fiyat olmadı̆̆ını göstermektedir. Ayrıca tüketiciler satın aldıkları çiğ sütün damak tatlarına uygun olmasına, çiğ sütün satış yerinden daha fazla önem vermektedirler.

Tüketiciler ilgili kurum ve kuruluşların çiğ süt ile ilgili bilgilendirme konusunda yetersiz olduklarını ve çiğ sütle ilgili 
temel bilgi kaynaklarının sosyal çevreleri olduğunu belirtmektedirler. Bu durum toplumda çiğ sütle ilgili bilimsel olmayan yanlış ya da eksik bilgilerin artmasına ve çiğ süt talebinin bundan olumsuz yönde etkilenmesine neden olabilir.

Özellikle gelir düzeyi yüksek olan tüketicilerin çiğ sütü mandıralardan tercih ettikleri ve çiğ süte daha fazla ücret ödedikleri belirlenmiştir. Ayrıca eğitim düzeyi yüksek tüketicilerin de çĭ̆ sütü büyük oranda mandıralardan satın aldıkları saptanmıştır. $\mathrm{Bu}$ durumda eğitim ve gelir düzeyi yüksek olan bireylerin çiğ sütün sokak satıcıları yerine soğuk zincire sahip olan çiğ süt satıcılarından alınması gerektiği konusunda daha bilinçli oldukları söylenebilir.

Çiğ sütün soğuk zincirde pazarlanmasının gelecekte kayıt dıșı pazarlanan süt oranını azaltacağ Üretilen çiğ süt kalitesinin artırılmasını sağlamak için soğuk süt zinciri oluşturulmasına ilişkin kooperatiflere yönelik proje ve desteklerin arttırılması gerekmektedir.

Tüketicinin sağlıklı ve hijyenik koşullarda çiğ süt tüketebilmesi için sütmatik/otomatik makinelerde çiğ süt satışının yaygınlaştırılması, sokakta süt satışının önüne geçecektir. Böylece sokakta satılan süt ile mandıralarda soğuk zincirde sunulan ambalajlı ari çiğ süt tüketiciler nezdinde kolaylıkla ayırt edilebilecektir.

Günümüzde sosyal medyaya olan ilginin artmasıyla birlikte tanıtım amaciyla yayın organları ve yazılı medyanın kullanımı, tüketicilerin ambalajlı çiğ süt tüketimi konusunda bilinçlenmelerini sağlayacak ve ari çiğ süt taleplerini arttıracaktır.

Türkiye'de sorunlar mevzuat ile giderilmeye çalışılmaktadır. Ancak bu yöntem her zaman beklenen sonucu doğuramamaktadır. Bu nedenle toplumda üretici ve tüketici çıkarlarının dengelenmesi gerekir. Her üreticinin bir tüketici olduğunu da göz önüne alarak üreticiler arasında kurulacak bir üretim ve satış kooperatifi hem fiyat farklılıklarını ortadan kaldırıp üretici ve tüketici rantlarında artış meydana getirebilir hem de denetimin kolaylaşmasını sağlayarak mevzuata uygun çiğ süt arzının yolunu açabilir. Böylelikle küçük ölçekli işletmelerin sürdürülebilirliği ve tüketici sağlığının korunması sağlanabilir.

\section{Teşekkür}

$\mathrm{Bu}$ çalışma Türkiye Bilimsel ve Teknolojik Araştırma Kurumu (TÜBİTAK) tarafindan 2209/A Üniversite Öğrencileri Araştırma Projeleri Destek Programı kapsamında desteklenen 1919B011703509 başvuru numaralı projeden üretilmiştir. Finansal desteği için TÜBİTAK'a teşekkür ederiz.

\section{Kaynaklar}

Akbay C, Yıldız Tiryaki G (2007) Tüketicilerin ambalajlı ve açık süt tüketim alışkanlıklarının karşılaştırmalı olarak incelenmesi: Kahramanmaraş örneği. Kahramanmaraş Sütçü İmam Üniversitesi Fen ve Mühendislik Dergisi 10(1): 89-96.

Andiç S, Şahin K, Koç Ş (2002) Van merkez ilçe kentsel alanda süt tüketimi. Yüzüncü Yıl Üniversitesi, Ziraat Fakültesi Tarım Bilimleri Dergisi 12(2): 33-38.

Ayar A, Demirulus H (2000) Eğitim çağındaki gençlerin süt ve süt ürünleri tüketim alışkanlıklarının belirlenmesi üzerine bir araştırma. G1da Dergisi 25(5): 371-376.

Çebi K, Özyürek S, Türkyılmaz D (2018) Süt ve süt ürünleri tüketiminde tüketici tercihlerini etkileyen faktörler: Erzincan ili örneği. Yüzüncü Yıl Üniversitesi Tarım Bilimleri Dergisi 28(1): 70-77.
Çelik Y, Karlı B, Bilgiç A, Çelik Ş (2005) Şanlıurfa ili kentsel alanda tüketicilerin süt tüketim düzeyleri ve süt tüketim alışkanlıkları. Tarım Ekonomisi Dergisi 11(1): 5-12.

Çetinkaya A (2010) Kafkas Üniversitesi öğrencilerinin içme sütü ve süt ürünlerini tüketim alışkanlıklarının belirlenmesi. Atatürk Üniversitesi Veteriner Bilimleri Dergisi 5(2): 73-84.

Demircan V, Örmeci MÇ, Kızılyar G (2011) Isparta ilinde ailelerin ambalajlı ve açık süt tüketim alışkanlıklarının karşılaştırmalı olarak incelenmesi. Süleyman Demirel Üniversitesi Ziraat Fakültesi Dergisi 6(2): 39-47.

Erdal G, Tokgöz K (2011) Tüketicilerin ambalajlı ve açık süt tüketim tercihlerini etkileyen faktörler: Erzincan ili örneği. Karamanoğlu Mehmetbey Üniversitesi Sosyal ve Ekonomik Araştırmalar Dergisi 13(20): 111-115.

Gözener B, Sayılı M (2013) Tüketicilerin açık süt ve süt ürünleri tüketim tercihlerinin incelenmesi: Tokat-Turhal ilçesi örneği. Sosyal Bilimler Araştırmaları Dergisi I(2013): 160-175.

Günlü A (2011) Çiğ süt pazarlanmasında süt sanayi işletmelerinde firma yoğunlaşma oranlarının araştırılması: Burdur ili örneği. Kafkas Üniversitesi Veteriner Fakültesi Dergisi 17(1): 101-106.

Kahraman EM (2016) İçme sütü tüketim alıșkanlıkları ve marka seçiciliğinde etkili faktörlerin analizi. Ege Üniversitesi, Fen Bilimleri Enstitüsü, Süt Teknolojisi ABD., Doktora Tezi, İzmir.

Karakaya E, Akbay C (2014) İstanbul ili kentsel alanda tüketicilerin açık ve paket süt tüketim alışkanlıkları. Tarım Ekonomisi Dergisi 20(1): 17-27.

Newbold P (1995) Statistics for Business and Economics. Prentice-Hall International, New Jersey.

Resmî Gazete (2017) Çiğ sütün arzına dair tebliğ. http://www.resmigazete.gov.tr/eskiler/ 2017/04/20170427-2.htm. Erişim 5 Eylül 2017.

Şimşek O, Çetin C, Bilgin B (2005) İstanbul ilinde içme sütü tüketim alışkanlıkları ve bu alışkanlıkları etkileyen faktörlerin belirlenmesi üzerine bir araştırma. Tekirdağ Ziraat Fakültesi Dergisi 2(1): 23-35.

Tekinşen OC, Tekinşen KK (2005) Süt ve süt ürünleri temel bilgiler teknoloji kalite kontrolü. Selçuk Üniversitesi. Basımevi, 1. Baskı, Konya, s. 1-1.

TÜIKK (2016) Adrese Dayalı Nüfus Kayı Sistemi. http://www.tuik.gov.tr. Erişim 5 Eylül 2017.

USK (2019) Dünya ve Türkiye'de Süt Sektör İstatistikleri. https://ulusalsutkonseyi.org.tr/raporlar/. Erişim 24 Aralık 2019.

Uzundumlu AS, Birinci A (2013) Tüketicilerin açık süt tüketimini etkileyen faktörlerin analizi: Erzurum ili örneği. Alınteri Zirai Bilimler Dergisi 25(2): 1-12. 